\section{Temporal Effects of Chemical Weed Control on Tart Cherry Tree Growth, Yield, and Leaf Nitrogen Concentration}

\author{
Yahya K. Al-Hinai ${ }^{1}$ and Teryl R. Roper ${ }^{2}$ \\ Department of Horticulture, University of Wisconsin-Madison, Madison, WI53706
}

Additional index words. herbicides, paraquat, leaf nitrogen, leaf area, internode, orchard floor management, damage threshold, weed competition

\begin{abstract}
This experiment was conducted to determine temporal weed management parameters for tart cherry (Prunus cerasus L.) orchards. Annual ryegrass (Lolium multiflorum L.) and lambsquarter (Chenopodium album L.) were planted in tree rows of a 4-year-old tart cherry orchard. Weeds either were not controlled or controlled with nonresidual herbicides during the following intervals: all-summer; May, June, July, or August; preharvest (April-July); or postharvest (late July to frost). Trees in all-summer, June, and preharvest weed-free plots had more shoot growth, more nodes, longer internodes, greater leaf area, and higher concentrations of leaf nitrogen than did those in the weedy control and postharvest, July, or August treatments. A larger increase in trunk circumference was observed in all-summer and preharvest weed-free plots than in postharvest and weedy plots. Early-summer weed control was important for tree vegetative growth. Tree yield (fruit weight and number) was greater on trees without weed competition postharvest than in those treated in May, June, July, or in weedy controls. Late-season (after late July) weed control is therefore important for fruit yield.
\end{abstract}

Weeds can cause substantial yield losses in orchards as a result of direct competition with fruit trees for water and nutrients (McMurtrie and Wolf, 1983). Weed effects on yield can also be indirect; weeds may compete for bee visits, thus reducing fruit pollination (Free, 1968), or may harbor pest populations (Meagher and Meyer, 1990).

Received for publication 10 Jan. 2000. Accepted for publication 13 July 2000. Partial support provided by the Wisconsin Red Cherry Growers Association. The cost of publishing this paper was defrayed in part by the payment of page charges. Under postal regulations, this paper therefore must be hereby marked advertisement solely to indicate this fact. ${ }^{1}$ Graduate Research Assistant.

${ }^{2}$ Professor; to whom reprint requests should be addressed. E-mail: trroper@facstaff.wisc.edu
Several studies on critical timing of herbicide application have been conducted with specific fruit species. Merwin and Ray (1997) observed that early-season weed control was more critical than late-season control for apple (Malus $\times$ domestica Borkh.) trees. However, their observations may not apply to cherries because spur leaves of apple appear before the flowers open, so some carbohydrates are available from current-season photosynthesis. The main objective of this project was to determine the most critical time for weed control in tart cherry orchards.

\section{Materials and Methods}

The experiment was conducted at the Univ. of Wisconsin-Madison Peninsular Agricultural Research Station near Sturgeon Bay, Wis. A 4-year-old tart cherry orchard cv.
Montmorency/Mahaleb, planted in a Longrie silt loam soil, $\mathrm{pH} 7$, with $4 \%$ soil organic matter, was used for the study. Weed-free times (WFT) were established for individual trees during the following intervals: May, June, July, or August; preharvest (April-late July); postharvest (late July-frost); or all-summer. A weedy control served for comparison. The experimental design was completely random with eight single tree replications per treatment.

In early May 1998, annual ryegrass and common lambsquarter were seeded in the tree rows. The area around individual trees was kept vegetation-free during the appropriate period with the nonresidual postemergent herbicide paraquat (1,1'-dimethyl-4,4'bipyridinium ion), applied at $0.5 \mathrm{~kg} \cdot \mathrm{ha}^{-1}$ with a surfactant (B1956 at $\left.156 \mu \mathrm{L} \cdot \mathrm{L}^{-1}\right)$. When the vegetation-free time had expired, annual ryegrass was seeded into the plots to provide competition for the trees. Irrigation was applied throughout the orchard by a single trickle line adjacent to trees along each row, providing $3.8 \mathrm{~L} \cdot \mathrm{h}^{-1}$ (65 L/week). Trees were fertilized annually in April, by broadcast application of ammonium nitrate at a rate of $118 \mathrm{~g}$ total $\mathrm{N} /$ tree in 1998 and $158 \mathrm{~g}$ total $\mathrm{N} /$ tree in 1999. Treatments were repeated in 1999 using the same trees as in 1998. During the 2 years of study, leaf samples were collected each month for tissue $\mathrm{N}$ analysis. Total shoot growth measurements were taken on 10 randomly selected shoots about shoulder height in early Aug. 1998 to measure tree growth and vigor. In early July 1999, four shoots per tree were collected to measure shoot length, number of nodes, internode length, and leaf area per shoot. All fruits from each tree were counted and weighed at harvest in late July 1999. Trunk circumference was measured in Fall 1999.

Data were subjected to analysis of variance and means were separated by Duncan's multiple range test when $F$ values were significant.

\section{Results}

Leaf $\mathrm{N}$ was generally higher in 1998 for the weed-free and preharvest (April-late July)

Table 1. Effect of timing of weed control and date of sampling on N concentration (percent dry weight) of tart cherry leaves in 1998 and 1999 at Sturgeon Bay, Wis. $(\mathrm{n}=8)$.

\begin{tabular}{|c|c|c|c|c|c|c|c|c|c|}
\hline \multirow[b]{2}{*}{$\begin{array}{l}\text { Date } \\
\text { of sampling }\end{array}$} & \multicolumn{8}{|c|}{ Treatment } & \multirow[b]{2}{*}{ Significance } \\
\hline & $\begin{array}{l}\text { Weed-free } \\
\text { all summer }\end{array}$ & Weedy & May & June & July & August & Preharvest & Postharvest & \\
\hline \multicolumn{10}{|c|}{1998} \\
\hline 2 June & $3.16 \mathrm{a}^{\mathrm{z}}$ & $3.13 \mathrm{ab}$ & $3.11 \mathrm{ab}$ & $2.97 \mathrm{ab}$ & $3.01 \mathrm{ab}$ & $2.93 \mathrm{~b}$ & $3.13 \mathrm{ab}$ & $2.93 \mathrm{~b}$ & NS \\
\hline 1 July & $3.57 \mathrm{a}$ & $2.50 \mathrm{~d}$ & $3.08 \mathrm{c}$ & $3.31 \mathrm{bc}$ & $2.45 \mathrm{~d}$ & $2.51 \mathrm{~d}$ & $3.41 \mathrm{ab}$ & $2.40 \mathrm{~d}$ & $* * *$ \\
\hline 30 July & $3.49 \mathrm{a}$ & $2.60 \mathrm{c}$ & $2.92 \mathrm{~b}$ & $3.10 \mathrm{~b}$ & $3.00 \mathrm{~b}$ & $2.54 \mathrm{c}$ & $3.51 \mathrm{a}$ & $2.53 \mathrm{c}$ & $* * *$ \\
\hline 31 Aug & $2.87 \mathrm{a}$ & $2.28 \mathrm{~d}$ & $2.25 \mathrm{~d}$ & $2.46 \mathrm{bc}$ & $2.53 \mathrm{~b}$ & $2.32 \mathrm{~d}$ & $2.81 \mathrm{a}$ & $2.37 \mathrm{~cd}$ & $* * *$ \\
\hline $1 \mathrm{Oct}$ & $2.67 \mathrm{a}$ & $2.14 \mathrm{~cd}$ & $2.13 \mathrm{~d}$ & $2.21 \mathrm{~cd}$ & $2.23 \mathrm{~cd}$ & $2.24 \mathrm{~cd}$ & $2.52 \mathrm{~b}$ & $2.26 \mathrm{c}$ & $* * *$ \\
\hline \multicolumn{10}{|c|}{1999} \\
\hline 1 June & $4.19 \mathrm{a}$ & $3.75 \mathrm{~b}-\mathrm{d}$ & $4.05 \mathrm{ab}$ & $3.45 \mathrm{~d}$ & $3.47 \mathrm{~cd}$ & $3.79 \mathrm{bc}$ & $3.76 \mathrm{~b}-\mathrm{d}$ & $4.17 \mathrm{a}$ & $* * *$ \\
\hline 1 July & $3.81 \mathrm{a}$ & $2.88 \mathrm{c}$ & $3.37 \mathrm{~b}$ & $3.33 \mathrm{~b}$ & $2.73 \mathrm{c}$ & $2.97 \mathrm{c}$ & $3.45 \mathrm{~b}$ & $2.93 \mathrm{c}$ & $* * *$ \\
\hline 2 Aug. & $3.03 \mathrm{a}$ & $2.40 \mathrm{de}$ & $2.34 \mathrm{e}$ & $2.51 \mathrm{~cd}$ & $2.78 \mathrm{~b}$ & $2.61 \mathrm{c}$ & $3.09 \mathrm{a}$ & $2.49 \mathrm{~cd}$ & $* * *$ \\
\hline 1 Sept. & $2.88 \mathrm{a}$ & $2.30 \mathrm{e}$ & $2.53 \mathrm{~cd}$ & $2.30 \mathrm{e}$ & $2.48 \mathrm{de}$ & $2.66 \mathrm{~b}-\mathrm{d}$ & $2.87 \mathrm{ab}$ & $2.73 \mathrm{a}-\mathrm{c}$ & $* * *$ \\
\hline $1 \mathrm{Oct}$ & $2.73 \mathrm{a}$ & $2.07 \mathrm{~d}$ & $2.15 \mathrm{~cd}$ & $2.10 \mathrm{~d}$ & $2.23 \mathrm{c}$ & $2.47 \mathrm{~b}$ & $2.50 \mathrm{~b}$ & $2.50 \mathrm{~b}$ & $* * *$ \\
\hline
\end{tabular}

${ }^{2}$ Mean separation within rows and years by Duncan's multiple range test, $P \leq 0.05$.

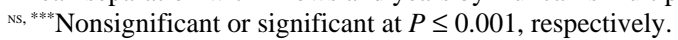


WFT than for the weedy controls or postharvest (late July-frost) and August WFT (Table 1). During 1999, trees kept weed-free the entire growing season had the highest $\mathrm{N}$ concentration in their leaves in July, August, and October. In July 1999 postharvest, July and August WFT and weedy plots had lower leaf N concentrations than did preharvest, May, June, or all-summer WFT plots. Generally, the concentration of leaf $\mathrm{N}$ was higher in 1999 than in 1998. Also, sampling date had a highly significant effect on leaf $\mathrm{N}$ concentration (Table 2). As would be expected, leaf $\mathrm{N}$ was higher in May and June than in August, September, or October.

Shoot length during 1998 and 1999 was greater on trees with all-summer, June, and preharvest WFT than in the weedy control and postharvest, July, or August WFT trees (Table 3). In 1998, May WFT trees grew more than did July, August, or postharvest WFT trees. Shoots on trees with no weed competition allsummer, May, June, and preharvest had more nodes than did July and postharvest WFT trees and weedy controls (Table 3). All-summer, May, June, or preharvest WFT trees had longer internodes than did all other WFT trees or the weedy control in 1998 (Table 3), but in 1999 no differences between treatments were significant.

Leaf area and leaf dry matter were greater in all-season, preharvest, May, and June weedfree plots than in weedy controls or late-season treatments (Table 3). Leaf area was almost $50 \%$ less on trees with no weed control than in July weed-free trees (Table 3 ).

All-summer, June, and preharvest WFT trees had greater leaf area per shoot than did the weedy controls, July, and postharvest WFT trees; May and August WFT trees were intermediate (Table 3). Specific leaf weight was not affected by treatment (data not shown). All-summer and preharvest WFT produced larger increases in trunk circumference than did all other treatments. Trunk circumference increase in control plots was half that in plots in which weeds were controlled during the entire growing season.

Fruit yield and fruit number per tree at harvest in 1999 were greater with no weed competition postharvest than with weedy, May, June, and July WFT (Table 4). There were no differences in fruit yield among weed-free, preharvest, postharvest, and August WFT trees. Individual fruit weight on trees that were weedfree during May, August, and postharvest tended to be greater than on those that were weed-free only in June, July, preharvest, or all-summer WFT.

\section{Discussion}

Our results show the effect of early-summer weed competition on the vegetative growth of tart cherry trees. During 1998, leaf nitrogen concentration was higher in trees kept weedfree early in the growing season (preharvest) or all season than in those with late-season WFT (July, August, or postharvest) or on the full-season weedy control. Merwin and Ray (1997) reported a similar trend for apple trees.

Table 2. Analysis of variance for tart cherry leaf N concentration (percent dry weight) during 1998 and 1999 as influenced by timing of weed control (Treatment), year of growth (Year), date of sampling (Date), and their interactions $(\mathrm{n}=8)$.

\begin{tabular}{lrcrrr}
\hline \hline Source & df & Sum of squares & Mean squares & F value & Pr $>$ F \\
\hline Year & 1 & 5.258 & 5.258 & 115.80 & $<0.0001$ \\
Treatment & 7 & 27.449 & 3.921 & 86.36 & $<0.0001$ \\
Year $\times$ treatment & 7 & 4.284 & 0.612 & 13.48 & $<0.0001$ \\
Date & 4 & 96.873 & 24.218 & 533.34 & $<0.0001$ \\
Year $\times$ date & 4 & 20.287 & 5.072 & 111.69 & $<0.0001$ \\
Treatment $\times$ date & 28 & 16.79 & 0.6 & 13.21 & $<0.0001$ \\
Year $\times$ treatment $\times$ date & 28 & 2.057 & 0.073 & 1.62 & 0.025 \\
Error & 560 & 25.429 & 2.189 & & \\
Corrected total & 639 & 198.428 & 0.045 & & \\
\hline
\end{tabular}

Table 3. Growth responses of tart cherry trees to timing of weed control during 1998 and 1999 at Sturgeon Bay, Wis. $(n=8)$.

\begin{tabular}{|c|c|c|c|c|c|}
\hline Treatment & $\begin{array}{l}\text { Shoot } \\
\text { length } \\
(\mathrm{cm})\end{array}$ & $\begin{array}{c}\text { Nodes } \\
\text { (no.) }\end{array}$ & $\begin{array}{c}\text { Internode } \\
\text { length } \\
(\mathrm{mm})\end{array}$ & $\begin{array}{c}\text { Leaf area/ } \\
\text { shoot } \\
\left(\mathrm{cm}^{2}\right)\end{array}$ & $\begin{array}{c}\text { Trunk } \\
\text { circumference } \\
\text { increase }(\mathrm{mm})\end{array}$ \\
\hline & \multicolumn{5}{|c|}{1998} \\
\hline Weed-free & $48.8 \mathrm{ab}^{\mathrm{z}}$ & $24.5 \mathrm{a}$ & $19.9 \mathrm{a}$ & $---y^{y}$ & $---y$ \\
\hline Weedy & $24.6 \mathrm{c}$ & $15.5 \mathrm{c}$ & $15.4 \mathrm{c}$ & --- & --- \\
\hline May & $42.1 \mathrm{~b}$ & $20.8 \mathrm{~b}$ & $19.9 \mathrm{a}$ & --- & --- \\
\hline June & $51.3 \mathrm{a}$ & $24.8 \mathrm{a}$ & $20.7 \mathrm{a}$ & --- & --- \\
\hline July & $30.6 \mathrm{c}$ & $17.3 \mathrm{c}$ & $17.7 \mathrm{~b}$ & --- & --- \\
\hline August & $30.2 \mathrm{c}$ & $17.1 \mathrm{c}$ & $17.3 \mathrm{~b}$ & --- & --- \\
\hline Preharvest & $49.0 \mathrm{ab}$ & $24.4 \mathrm{a}$ & $19.9 \mathrm{a}$ & --- & --- \\
\hline Postharvest & $25.6 \mathrm{c}$ & $15.9 \mathrm{c}$ & $18.3 \mathrm{bc}$ & --- & --- \\
\hline \multirow[t]{2}{*}{ Significance } & $* * * \mathrm{z}$ & $* * *$ & $* * *$ & & \\
\hline & \multicolumn{5}{|c|}{1999} \\
\hline Weed-free & $35.8 \mathrm{a}$ & $19 \mathrm{a}$ & $18.9 \mathrm{a}$ & $430.8 \mathrm{ab}$ & $40.8 \mathrm{a}$ \\
\hline Weedy & $28.5 \mathrm{bc}$ & $16.4 \mathrm{~b}$ & $17.3 \mathrm{a}-\mathrm{c}$ & $331.6 \mathrm{~cd}$ & $20.4 \mathrm{c}$ \\
\hline May & $31.8 \mathrm{ab}$ & $18.5 \mathrm{a}$ & $17.2 \mathrm{a}-\mathrm{c}$ & $406.5 \mathrm{a}-\mathrm{c}$ & $28.9 \mathrm{~b}$ \\
\hline June & $35.9 \mathrm{a}$ & $19.3 \mathrm{a}$ & $18.7 \mathrm{ab}$ & $466.9 \mathrm{a}$ & $28.1 \mathrm{~b}$ \\
\hline July & $24.1 \mathrm{c}$ & $14.1 \mathrm{c}$ & $17.0 \mathrm{bc}$ & $261.5 \mathrm{~d}$ & $29.6 \mathrm{~b}$ \\
\hline August & $29.3 b$ & $17.7 \mathrm{ab}$ & $16.7 \mathrm{c}$ & $362.9 \mathrm{bc}$ & $26.3 \mathrm{bc}$ \\
\hline Preharvest & $35.4 \mathrm{a}$ & $19.0 \mathrm{a}$ & $18.6 \mathrm{ab}$ & $441.6 \mathrm{ab}$ & $36.6 \mathrm{a}$ \\
\hline Postharvest & $30.2 \mathrm{~b}$ & $16.4 \mathrm{~b}$ & $18.3 \mathrm{a}-\mathrm{c}$ & $336.9 \mathrm{~cd}$ & $23.7 \mathrm{bc}$ \\
\hline Significance & $* * *$ & $* * *$ & NS & $* * *$ & $* * *$ \\
\hline
\end{tabular}

${ }^{2}$ Mean separation within columns and years by Duncan's multiple range test.

y Data not recorded.

Ns, ${ }^{* * *}$ Nonsignificant or significant at $P \leq 0.001$, respectively.

Although all trees in our study received the same amount of $\mathrm{N}$ fertilizer, leaf $\mathrm{N}$ concentration recovered in trees with July WFT, suggesting that even midsummer weed control can improve leaf $\mathrm{N}$ concentration in tart cherry. In 1999, leaf N was higher in July, August, and October when weeds were controlled during the entire growing season. August data indicated that trees with preharvest (May-late July) WFT also had higher leaf N concentrations. This suggests that weeds were successfully competing for $\mathrm{N}$ early in the growing season. Treatment $\times$ year interaction was significant, indicating that leaf $\mathrm{N}$ concentration had increased over time, perhaps due to weed control the previous year or because the trees grew more during 1999, allowing them to be more efficient in $\mathrm{N}$ uptake. Also, date $\times$ treatment interaction was significant, suggesting that leaf $\mathrm{N}$ concentrations were not constant throughout the season. Higher leaf $\mathrm{N}$ concentration was found early in the growing season, when stored reserves were just beginning to be used by early growth and fruit development.

Controlling weeds all season or early in the season increased tree growth. Itoh et al. (1997) observed the same for peach [Prunus persica
Table 4. Fruit yield and fruit number of tart cherry trees during 1999 in relation to weed-free times during 1998 and 1999 and Sturgeon Bay, Wis. (n $=8)$.

\begin{tabular}{lccc}
\hline \hline & $\begin{array}{c}\text { Fruit wt } \\
(\mathrm{kg} / \mathrm{tree})\end{array}$ & $\begin{array}{c}\text { Fruit no. } \\
(\text { no./tree })\end{array}$ & $\begin{array}{c}\text { Individual } \\
\text { fruit wt } \\
(\mathrm{g} / \text { fruit })\end{array}$ \\
\hline Wreatment & $5.2 \mathrm{a}-\mathrm{c}^{\mathrm{z}}$ & $1248 \mathrm{ab}$ & $4.2 \mathrm{bc}$ \\
Weedy & $3.9 \mathrm{bc}$ & $893 \mathrm{~b}$ & $4.3 \mathrm{a}-\mathrm{c}$ \\
May & $3.8 \mathrm{bc}$ & $867 \mathrm{~b}$ & $4.4 \mathrm{a}$ \\
June & $4.2 \mathrm{bc}$ & $984 \mathrm{~b}$ & $4.1 \mathrm{c}$ \\
July & $3.7 \mathrm{c}$ & $909 \mathrm{~b}$ & $4.1 \mathrm{c}$ \\
August & $5.3 \mathrm{ab}$ & $1220 \mathrm{ab}$ & $4.4 \mathrm{a}$ \\
Preharvest & $5.0 \mathrm{a}-\mathrm{c}$ & $1190 \mathrm{ab}$ & $4.2 \mathrm{bc}$ \\
Postharvest & $6.1 \mathrm{a}$ & $1411 \mathrm{a}$ & $4.4 \mathrm{a}$ \\
Significance & $*$ & $*$ & $*$ \\
\hline
\end{tabular}

"Mean separation within columns by Duncan's multiple range test, $P \leq 0.05$

* Significant at $P \leq 0.05$.

(L.) Batsch.]. Perhaps growth was less in our May WFT plots than in June WFT plots during 1998 because both leaf and fruit growth occurred during May; thus, demand for carbohydrates and $\mathrm{N}$ would be highest at this time (Keller and Loesche, 1989; Roper et al., 1988).

In 1998, trees with all-summer, preharvest (April-late July), May, and June WFT produced longer internodes, indicating more 
growth. On the other hand, trees in weedy plots and those with July, August, and postharvest WFT had shorter internodes, probably because of their slower growth. Poll (1973) found the same trend in apple, with internode length being affected by growth rate. In 1999, weed suppression during the early season increased leaf area, further indicating that early summer was the most critical time for weed competition with vegetative growth.

All-summer and preharvest WFT increased trunk circumference more than did late summer or no control. These results indicate that tart cherry tree growth is influenced at the critical time of demand for photoassimilates, perhaps because weed competition early in the growing season reduces leaf $\mathrm{N}$ and concomitantly the rate of photosynthesis (Jordan, 1981).

Cherries have only 2 months from flowering until fruit maturity. Fruit growth, shoot growth, and flower bud initiation all occur at the same time, and competition for substrates can occur among several sinks. Postharvest weed control increased yields more than did May, July, or July WFT, probably because weeds were controlled during the critical time for accumulation of the carbohydrates that would subsequently be used for flower bud development. High yields were associated with greater fruit numbers, not larger size. Roper et al. (1988) showed that carbohydrate reserves drop in woody tissues prior to harvest. They concluded that the period between harvest and leaf fall is the critical time for carbohydrate accumulation to support early spring growth the following year. Because they open before the leaves, cherry flowers are entirely dependent on stored reserves for flower and early fruit development. Keller and Loescher (1989) stated that, for bud burst and initial growth, cherry trees rely heavily on stored reserves from the previous year. We obtained the same results during the second year of this study, indicating that controlling weeds late in the growing season probably affects yield the following year. May, August, and postharvest WFT trees had higher individual fruit weight than did all-summer, June, July, and preharvest WFT trees, probably for the same reasons.

In conclusion, this research shows that early-summer weed control in tart cherries is more important than late-summer control for vegetative growth, whereas late-season weed control is important for fruit yield the following year. Thus, growers would be well advised to manage weeds throughout the growing season

\section{Literature Cited}

Free, J.B. 1968. Dandelion as a competitor to fruit trees for bee visits. J. Appl. Ecol. 5:169-178.

Itoh, M., S. Kobayashi, K. Manabe, and M. Takahashi. 1997. Effect of timing of winter weed control on the growth of young peach trees under sod culture. J. Jpn. Soc. Hort. Sci. 66:1-8.

Jordan, L.S. 1981. Weeds affect citrus growth, physiology, yield, fruit quality. Proc. Intl. Soc. Citricult. 2:481-483.

Keller, J.D. and W.H. Loescher. 1989. Nonstructural carbohydrate partitioning in perennial parts of sweet cherry. J. Amer. Soc. Hort. Sci. 114:969975.

McMurtrie, R. and L. Wolf. 1983. A model of competition between trees and grass for radiation, water and nutrients. Ann. Bot. 52:449-458.

Meagher, R.J., Jr., and J.R. Meyer. 1990. Effects of ground cover management on certain abiotic and biotic interactions in peach orchard ecosystems. Crop Protection 9:65-72.

Merwin, I.A. and J.A. Ray. 1997. Spatial and temporal factors in weed interference with newly planted apple trees. HortScience 32:633-637.

Poll, L. 1973. The relationship between internode length and shoot length in apple. Hort. Res. 13:83-88.

Roper, T.R., J.D. Keller, W.H. Loescher, and C.R. Rom. 1988. Photosynthesis and carbohydrate partitioning in sweet cherry: Fruiting effects. Physiol. Plant. 72:42-47. 